\title{
Building a Literature Culture in Islamic Education Units: Concept and Strategy
}

\author{
Saefrudin
}

Islamic Religion Faculty, Universitas Islam Sultan Agung, Indonesia

\author{
Correspondence: \\ saefrudintbi@gmail.com
}

$\begin{array}{llll}\text { Received: } & \text { Revised: } & \text { Accepted: } & \text { Published: } \\ \text { 30 June 2021 } & \text { 17 July 2021 } & \text { 27 July 2020 } & \text { 13 August 2021 }\end{array}$

\begin{abstract}
In the 21st century, the ability of literate learners closely related to the demands of reading skills that lead to the ability to understand information in an analytical, critical, and reflective. Based on the current reality in most educational institutions in Indonesia, especially in the institutions of Islamic formal education encountered problems related to the acculturation of literacy in schools. The problems include low interest in reading, reading motivation among learners, and demands the ability to read in the sense of understanding the text analytical, critical, and reflective. Thus, several attempts were made to develop a culture of reading is to: a) Allowing learners to read at least 15 minutes before the learning activity begins; b) Setting up a library or reading room comfortable and enjoyable at school; c) Absolutely the proper functioning of the library as a means of learningresources; d) Enhancing the reading material with the procurement of varied and interestingbooks in the school; e) create symbols that can enhance the enthusiasm of the spirit of reading; and f) Hold a book review contest among students / classes regularly at school. Of course, for students who win should be given an appreciation / reward.
\end{abstract}

Keywords: cultural literacy; Islamic education institutions

\section{INTRODUCTION}

Recognized or not, the benchmark of a nation's quality is seen from the extent to which education is able to produce reliable human beings. The nation will be qualified if its human beings are also qualified (Yamin, 2009). The essence of education is the interaction between students and teachers related to learning materials and the environment, or better known as the teaching and learning process or the learning process (Zamroni, 2003).

Education is an investment in human resources (human investment). Including quality books is synonymous with investment in achieving the nation's progress in the future. Familiarizing the educational community with books presupposes the creation of a "reading culture" social order in which books become a necessity that inspires and motivates a higherquality of life (Fadjar, 2005).

One of the important things in learning is reading textbooks that contain written subject matter to be read in the form of packages or other books related to the subject 
(Sagala, 2007). In relation to the use of learning resources, students can use the library as a means to provide information related to lessons.

In the 21 st century, students' literacy skills are closely related to the demands of reading skillswhich lead to the ability to understand information analytically, critically, and reflectively. Based on this, the Ministry of Education and Culture developed the School Literacy Movement (GLS). GLS is a comprehensive effort to turn schools into learning organizationswhose citizens are literate for life through public involvement.

Based on the current reality in most educational institutions in Indonesia, especially in formal Islamic educational institutions, there are many problems related to literacy culture in schools. These problems include: low interest in reading, motivation to read among students, and demands for reading skills in terms of understanding texts analytically, critically, andreflectively.

Based on the introduction above, the authors can propose the following problems: "What is the strategy to overcome the low interest in reading students at school?"

\section{DISCUSSION}

\section{Literacy Concept}

In language learning, literacy is defined as literacy, literacy, literacy or proficiency in reading and writing (Alwasilah, 2001). Baynham (1995) states that literacy is an integration of listening, speaking, writing, reading, and critical thinking skills. Gee (1991) interprets literacy from an ideological perspective of discourse which states that literacy is "mastery of, or fluent control over, a secondary discourse." In providing this understanding, Gee uses the premise that literacy is a skill that a person has from thinking, speaking, reading, and writing activities.

Stripling (1992) states that "literacy means being able to understand new ideas well enough to use them when needed. Literacy means knowing how to learn". This understanding is based on the basic concept of literacy as literacy so that the scope of literacy revolves around all efforts made in understanding and mastering information. Above all, it can be stated that literacy is (1) the ability to read and write or literacy; (2) the abilityto integrate listening, speaking, reading, writing and thinking; (3) the ability to be ready to use in mastering new ideas or how to learn them; (4) ability tools to support success in an academic or social environment; (5) the ability to read and write performance that is always needed; (6) the competence of an academic in understanding discourse professionally.

From the concept of literacy in other countries, literacy models have been developed, for example (1) ESL (English as a Second Language) Literacy Model (Ranard and Pfleger, 1993); (2) Ocotillo Information Literacy Competencies Model (Evans, 1994); (3) Developing an Instructional Literacy Model. (Davis, 1996); (4) Mediation for Dynamic Literacy Instruction Model (Dixon-Krauss, 2000); (5) The Information Literacy Model (Sigmon, 2000); and (6) Model Construct Meaning (Cooper, 1993). These models have succeeded in increasing students' abilities for the 
necessities of life in a literate society, both academicallyand in other social activities.

\section{The Reality of Literacy in Indonesia}

It is undeniable that the reading interest of the Indonesian people is still relatively low. Based on the UNESCO survey, the reading interest of the Indonesian people is only 0.001 percent. That is, in a thousand communities there is only one community who has an interestin reading. The Head of the Public Service Communication Bureau (BKLM) of the Ministryof Education and Culture Asianto Sinambela emphasized that Indonesian people's interest in reading literacy is still lagging behind other countries. Of the 61 countries, Indonesia is ranked 60th. According to Asianto, this shows that the reading ability of the Indonesian people is still equivalent to that of South Africa. "Our reading literacy score is still very low. We admit, the average research value of the Program for International Student Assessment (PISA) is 493, while the Indonesian literacy score is only 396," he said as quoted from Indopos (Jawa Pos Group) (http://gobekasi.pojoksatu.id/2016/05)./19/survei-unesco-interest-baca-communityindonesia-0001-persen/).

The low interest in reading in our society greatly affects the quality of the Indonesian people, because with the low interest in reading, they cannot know and follow the development of science and information in the world, which in the end will have an impact on the backwardness of the Indonesian nation. Therefore, to be able to catch up with the progress that has been achieved by neighboring countries, we need to examine what makes them more advanced. It turns out that they are superior in human resources. Their reading culture is ingrained and has become an absolute necessity in their daily lives. To follow in their footsteps in growing interest in reading from an early age, we need to imitate and applyit to our society, especially to the nation's young generation who will inherit this country. Thecivilization of a nation is determined by its intelligence and knowledge, while intelligence and knowledge are generated by the amount of knowledge acquired, while knowledge is obtained from information obtained orally or in writing. The more residents of an area who are thirsty for knowledge, the higher the civilization.

The culture of a nation usually goes hand in hand with literacy culture, cultural and civilizational factors are influenced by reading resulting from the findings of the intelligent people recorded in writing which makes the legacy of information literacy very useful for the dynamic process of social life. The low interest in reading in our society greatly affects the quality of the Indonesian people, because with the low interest in reading, they cannot know and follow the development of science and information in the world, which in the end will have an impact on the backwardness of the Indonesian nation. Therefore, to be able to catch up with the progress that has been achieved by neighboring countries, it is necessary to cultivate an interest in reading from an early age. If previously reading was synonymous withbooks or print media, in today's digital era, reading is no longer fixated on reading paper because all the latest information is available in cyberspace/internet and other electronic media.

Reading is part of the four components of language skills. The four language components include: Listening skills, speaking skills, reading skills, writing skills 
(Tarigan, 1992). Thus a person's language ability is largely determined by the mastery of these four components. At least this statement has been proven in the research of Aprilianawati's thesis (2008).

In Semarang that the contribution of reading interest to the variable of linguistic ability is $19.6 \%$. With regard to one of the components, namely "reading", it is well known that the quality of interest in reading from both children and adults in Indonesia is very low. Several international and national surveys report the following. UNESCO in 2012 noted that the reading interest index in Indonesia had only reached 0.001 . This means that in every 1,000 people, there is only one person who has an interest in reading. Meanwhile, UNDP released the adult literacy rate in Indonesia which is only 65.5 percent, while Malaysia has reached 86.4 percent (http://www.republika.co.id/berita/nasional/region/13/11/02/mvmvq4-library- interesteading-community-Indonesia-still-low).

Based on a survey conducted by the International Education Achievement (IEA) in early 2000, it shows that the reading quality of Indonesian children ranks 29th out of 31 countries studied in Asia, Africa, Europe and America. Thus, it is not surprising that the Human Development Index (HDI) in Indonesia is also low. This is in accordance with a survey conducted by UNDP in 2005 that Indonesia's HDI was ranked 117 th out of 175 countries (http://www.bimba-aiueo.com/kenapa-minat-baca-diindonesia-low/).

What about the condition of interest in reading in the region? Not much different from the national level, the results of research by Oktarina and Purwantini (2008), said that out of 140 respondents from the Semarang Maritime Science Polytechnic (PIP) cadets, only $16.4 \%$ had a passion for reading, $10,1 \%$ of cadets who have 18 books. Similarly, the conclusion of Wirawan (2013), in his thesis regarding activities in the Kebumen Library and Archives found the fact that the reading interest of the public and library visitors was still low. Indicators of low interest in reading cannot only be studied through the various research reports above, but we can see from the enthusiasm of the community in visiting libraries, both libraries in schools and libraries in the region. Likewise, the number of visitorsand buyers of bookstores is not so significant.

Why is our society's interest in reading so low? This fact cannot be separated from several factors that are closely related to each other. First, the government has not optimally realized Law No. 43 of 2007 concerning Libraries. The role of the governmentin cultivating interest in reading both in families, schools, regional libraries and reading gardens is regulated in articles 48-51. What is happening now is the provision of libraries and books, but the cultivation of interest in reading has not occurred optimally. Second, the education system in schools does not provide encouragement and access space for students tohave an interest in reading.

Taufik Ismail, a humanist said that in developed countries a number of high school graduates are required to complete a number of readings in one year. In America, youare required to read 32 titles of literary works in a year, in Japan 15 titles of literary works, inBrunei 72 titles of literary works, in Singapore and Malaysia 6 literary works and Thailand 5 titles of literary works. In the colonial era, AMS-B students (equivalent 
to high school) were required to read 15 literary titles per year while AMS-A students were required to read 25 literary works per year. AMS students are required to write 1 essay per week, 18 essays per semester or 36 essays per year (Kompas, January 16, 2014 p. 12).

Once in one of the teacher and parent meetings I asked why the school did not build a system that made children have a high interest in reading and access various information through the literature. The answer was very disappointing where one of the teachers just saidthat they leave it to the students and give them the freedom to read books other than the compulsory books at school. Third, families pass on a culture of listening rather than reading. It is almost rare to find every member of the community's house in which there is a shelf filledwith books in a row. Parents who do not have the habit of reading will have an impact on shaping the behavior of their family members into people who do not like to read. The 2010 Central Bureau of Statistics (BPS) report provides evidence that Indonesians have not made reading their main source of information. People prefer watching TV $(85.9 \%)$ or listening to radio $(40.3 \%)$ than reading newspapers $(23.5 \%)$.

Does the public's low interest in reading have a number of significant impacts? Of course. It does not only affect verbal and linguistic abilities in conveying ideas, but also the socio-cultural impact, namely the formation of a society that is more fond of meaningless conversations (gossip, hanging out) than filling their spare time by reading books, magazines, newspapers or other reading media Does the declaration of Jakarta as the number one chatty city in the world because tweeter social media activities generate 15 tweets per second have something to do with low reading interest? This phenomenon still needs further study. But the most significant impact, of course, hinders progress and mastery of technology. Almost all countries that have progressed in the field of technology or socio-economic life are nationsthat invest in knowledge through reading.

Tilaar (1999) states that to change the behavior of people who like to read requires /. change in the culture or behavior of our society, and even it requires a long process and time of about one or two generations (15-25 years) depending on the "political will of the government and society". To make a generation that is qualified and competitive, the learning process should foster a culture of note-taking and a good reading culture for students (Mulyasana, 2011). So that in the future our nation can be more qualified.

\section{Literacy in Islam}

The triumph of the scientific tradition in Islam cannot be separated from the spirit of literacy that thrives in the midst of the Muslim community. The literary tradition even has its traces in the traditions of the Arabs before Islam (Haikal, 1965). When Islam came, literary traditions and literacy traditions in general grew. The Abbasid period (750-1258 AD), precisely at the time of the rationalist caliph al-Ma'mun, increasingly revived the passion forliteracy in the Islamic world.

In the literacy tradition, there are two fundamental things that must be kept alive. That is reading and writing. A classic saying "writing is a miracle", writing is a miracle. 
Yes, writing is magic. And reading is the way to make this magic happen. The sluggish passion for science in the Islamic world a few centuries ago, was preceded by the slackening of the spiritof reading in the Muslim community.

In fact, reading has a very strong theological basis in Islamic teachings. The first revelation in Islam is the letter al-'alaq which begins with the word iqra', read it (alQurtubi, 2006). Allah SWT. started the prophetic procession of the Prophet Muhammad with the command to read. In other words, reading is the first prophetic message that marks the beginning of the descent of Islam. For this reason, reading is not only an instrumental activity. In Islam, reading is the actualization of a prophetic message. The strengthening of this prophetic argument must be put forward, in the midst of the low reading tradition in our society. In deep meaning, reading is not only based on textual objects. Reading also means revealing the meaning of contextual objects. Because the signs of God's power are not only visible in the textual form of the noble Qur'an (qauliyah verse), but also manifest in all eventsof the universe (kauniyah verse).

\section{Building a Literacy Culture}

From the facts that we have seen about learning Indonesian above, the direction of learning must be changed. Indonesian language learning is directed at efforts to build a literacy culture, especially learning that can increase students' activities using teaching materials in life. Students learn language or literature for the real world, not the world of school. Literacy-based learning is done by developing ideas orideas through developing questions at the time of writing, then developing them through the connection between ideas and the controversy of each idea. Literacy culture-based learning in education has advantages because the literacy model is not only intended so that students have the capacity to understand the conceptual meaning of discourse but the ability to participate fully actively in applying social and intellectual understanding.

Literacy culture-based learning will condition students to become literate. Improving literacy skills in learning is in line with educational goals, namely the development of the potential of students to become human beings who believe and fear God Almighty, have noble character, are healthy, knowledgeable, capable, creative, independent, and becomedemocratic and responsible citizens (Depdiknas, 2003).

Obtaining this goal can be done by students if they have become literate figures. The students have the provision of literacy in themselves so that they are able to equip themselves with the expected abilities Meanwhile, in relation to increasing interest in reading, there are opinions that say that efforts to improve reading culture in students are as follows:

a. Cultivate an interest in reading from an early age. This can be done by playing whilereading.

b. Provide books that are of interest to children.

c. Do not force children to always read.

d. Put books that are liked by children in a place that is easily accessible by children.

e. Choose books that educate children on good things, because children are very 
vulnerable to being infiltrated by bad things.

f. Get used to the children exchange books with each other, or take children to the libraryto overcome the inability to buy books.

g. Never give up trying something for your child. Rest assured, regardless of the age of theirchildren, they can certainly be directed to love books (Prasetiono, 2008).

The process of developing literacy skills is carried out by developing cognitive abilities, analysis, synthesis, evaluation, and creation through a direct study of social conditions using careful and critical thinking skills. The process of understanding students' social phenomenawith direct introduction will make it easier for students to develop their competencies. Students must be familiar with reading various information and accessing information from electronic media and written media. In addition, he needs to follow the development of civilization that is happening factually. Therefore, in developing literacy-based language and literary competence, it is necessary to support the availability of facilities in building literatepeople. The activities of educators in the classroom when carrying out literacy-based learningare lighter, namely (1) directing the activities of students; (2) selecting and preparing learning materials; (3) checking the work of students; (4) directing the scientific communication system; (5) coordinate in preparing the classroom setting for literacy activities.

Based on some of the descriptions above, some of the efforts made to develop a readingculture are by:

a. Familiarizing students to read at least 15 minutes before learning activities begin.

b. Preparing a library or reading room that is comfortable and fun at school.

c. Enriching reading materials by procuring varied and interesting books at school.

d. Making symbols that can increase enthusiasm for reading.

e. Holding a book review competition between students/classes periodically at school. Ofcourse, for students who win, should be given an appreciation / reward. 


\section{CONCLUSION}

From the discussion above, it can be concluded as follows: To change the condition of the low interest in reading in our society, the government, education centers (schools) and families, need to make systemic changes starting from the government, education centers and families. The government (Kemenag) is not only obliged to provide regional libraries and mobile libraries as well as reading books for the community, but also to cultivate interest in reading through special regulations that are passed on to the education system. The education center in this case the school not only emphasizes the pattern of teaching and listening to its students but also researches together through reading additional literature provided in the library in addition to the mandatory literature. The function of the library is maximized by encouraging the activities of students to conduct literature studies in the library to produce exploratory written works. The role of families and communities who are concerned with the development of reading interest can create a community library of people who collaborate with educational institutions or regional libraries to encourage people to read books. So that the community reading community through the people's library is effective, don't just wait for the community to come, but make the place a community learning center for free such as English courses, article writing courses, review activities for the latest books adapted to the intellectual absorption of the community and others.

By finding the root of the problem and the socio-cultural impact of the poor interest in reading in our society and optimizing the available solutions by involving many parties (government, education centers, families and communities) it is hoped that the cultivation of reading interest will produce the next generation of the nation that is rich with ideas exploratory to make social change and build the glory of the nation.

\section{REFERENCES}

al-Qurtubi, A. A. M. (2006). al-Jamī' li Ahkām al-Qur'an. Muassasahal-Risala.

Alwasilah, C. A. (2001). Writing is neglected in our school. Alwasilah, CA.

Aprilianawati, E. (2008). Students' Linguistic Ability Judging From Reading Interest. Semarang: Psychology Study Program UNIKA Soegijapranata.

Baynham, E. (1995). An introduction to the Metz Epitome: its traditions and value. Antichthon, 29, 60-77.

Fadjar, A. M. (2005). Holistic Thought Education. Editor: Ahmad Barizi. Raja Grafindo Persada.

Gee, J. (1991). Socio-cultural approaches to literacy (literacies). Annual review of applied linguistics, 12, 31-48.

Haikal, M. H. (1965). Trans. Ali Audah, "History of Muhammad's Life". Maktabah AlNahdhah al-Arabiyah.

http://www.bimba-aiueo.com/kenapa-minat-baca-di-indonesia-low/ 
http://www.republika.co.id/berita/nasional/region/13/11/02/mvmvq4-library- interesteading-community-Indonesia-still-low

Kompas. (January 16, 2014). Indonesia Only Publishes 24,000 Books, p. 12

Mulyasana, D. (2011). Quality and Competitive Education. Rosda Karya.

Oktarina, M., \& Purwantini, S. (2008). Analysis of the low reading interest of cadets at the Semarang Shipping Science Polytechnic Library (PIP). Journal of Marine Science Polytechnic Semarang.

Prasetiono, D. S. (2008). The Secret of Teaching Children to Love Reading from an Early Age. Think!

Sagala, S. (2007). The Concept and Meaning of Learning to Help Solve the Problems of Learning and Teaching. Alphabeta.

Stripling, B. K. (1992). Libraries for the national education goals.

Tarigan, H. T. (1992). Writing as a Language Skill. Space.

Tilaar, H. A. R. (1999). Several National Education Reform Agendas; In the 21st Century Perspective. Indonesia Tera, Jakarta.

Wirawan, A. (2013). A Study of the Kebumen Public Library: A SWOT Analysis, Thesis. University of Indonesia.

Yamin, M. (2009). Claiming Indonesian Education: Learning from Paulo Freire and Ki Hajar Dewantara. Arruz Media.

Zamroni. (2003). Education for Democracy. Bigraph. 